\title{
Influence of the Foraging Activity of the Anthophilous Insects on Talinum triangulare (Waterleaf) fructification in Bafut (North West - Cameroon)
}

\author{
Esther Nadine Otiobo Atibita ${ }^{1, a,{ }^{*}}$, David Fotsing ${ }^{1, \mathrm{~b}}$, Njoya Moses Tita Mogho ${ }^{1, \mathrm{c}}$, Champlain Djieto-Lordon ${ }^{2, \mathrm{~d}}$, \\ Fernand-Nestor Tchuenguem Fohouo ${ }^{3, \mathrm{e}}$
}

${ }^{1}$ University of Bamenda, Faculty of Science, Department of Biological Sciences, P.O. Box 39 Bambili, Cameroon.

${ }^{2}$ University of Yaounde I, Faculty of Science, Laboratory of Zoology, P.O. Box 812 Yaounde Cameroon.

${ }^{3}$ University of Ngaoundere, Faculty of Science, Laboratory of Applied Zoology, P.O. Box 454 Ngaoundere, Cameroon. *Corresponding author

\begin{tabular}{|c|c|}
\hline A R T I C L E I N F O & A B S T R A C T \\
\hline $\begin{array}{l}\text { Keywords: } \\
\text { Talinum triangulare } \\
\text { Insect species } \\
\text { Flowers }\end{array}$ & $\begin{array}{l}\text { Talinum triangulare is an herbaceous succulent plant eaten as a vegetable throughout the tropics } \\
\text { including many countries in West and Central Africa and are an essential ingredient in traditional } \\
\text { dishes. Experiments were made on the plant to examine the influence of foraging behavior of } \\
\text { flowering insect on pollination and yields of this plant species in } 2018 \text { and } 2019 \text { at Bafut. } \\
\text { Observations were made on } 1615 \text { to } 4055 \text { flowers per treatment. The treatments included unlimited } \\
\text { floral access by visitors and bagged flowers to deny all visits. The study focused on the foraging } \\
\text { behavior of flowering insects and their pollination activity (fruiting rate). The results show that } 14 \\
\text { insect species visited waterleaf flowers and Camponotus flavomarginatus was the most frequent } \\
\text { (33.20\%). Insects foraged throughout the day light period. Their activity was highest between } 10 \\
\text { am and } 12 \text { pm. Insect species foraged the flowers for pollen and nectar. The fructification rate of } \\
\text { unrestricted floral access was significantly high than that of protected flowers to deny all visits. The } \\
\text { maintenance of insect nest close to T. triangulare field is recommended to improve it fruits } \\
\text { production. }\end{array}$ \\
\hline
\end{tabular}

Fruiting rate

Africa production.

\begin{tabular}{l} 
\\
\hline atiobo@yahoo.fr \\
'@ njoyamoses@yahoo.com \\
nt.foho@gmail.com
\end{tabular}

(iD $h$ ttps//orcid.org/0000-0002-2554-0869 iD https//orcid.org/0000-0003-3144-7449 (iD) https//orcid.org/0000-0002-0962-2573 https//orcid.org/0000-0002-1453-9424 https//orcid.org/0000-0002-1098-9866

\section{Introduction}

Talinum triangulare is a non conventional vegetable crop which originates from tropical Africa and is widely grown in Asia, South America and West Africa (Schippers, 2000). It is an herbaceous succulent plant in the Portulacaceae family with common name as waterleaf, Ceylon spinach, fame flower (Siemonsna and piluck, 1993). Waterleaf is eaten as a vegetable throughout the tropics including many countries in West and Central Africa; it is cultivated in Nigeria and Cameroon; it is an essential ingredient in traditional dishes (Fontem and Schippers, 2004.). Waterleaf is a rich source of crude protein $(22 \%)$, crude fibre $(11.2 \%)$, ash $(33.98 \%)$ (Enete and Okon, 2010) and content approximately $90.8 \mathrm{~g}$ per $100 \mathrm{~g}$ of water (Herrera, 1999). Waterleaf is a short-lived plant that grows up to $30 \mathrm{~cm}$ to $100 \mathrm{~cm}$ in height (Opabode,
2005).The flowers are visited by pollinators due to the rich nectar they have (Stevels, 1990). The fruit is dehiscent. (Schippers, 2000). Storage is a bit difficult thus should be used immediately when harvested (Okpala, 2016). The vegetable is used as a softener when cooking fibrous vegetables like Gnetum africanum (eru) (Ndaeyo et al., 2013), aid in digestion of food (Mensah et al., 2008, Okpala, 2016) and act as green forage for rabbit feed management (Aduku and Olukosi, 1990)

Since the increased popularity of eru in Cameroon and eastern Nigeria from around 1990 onwards, the demand for waterleaf has steadily risen, thus widening the domestic demand and supply gap of the product. It is now a common product on local markets, but no data on production and trade are available (Fontem and Schippers, 2004). 
Waterleaf is a plant species for which information on insect pollination in Africa, particularly in Cameroon is still lacking. Much information exists for the species of waterleaf as food items (Nworgu et al., 2015; Ezekwe et al., 2013) and medicine (Aja et al., 2010; Liang et al., 2011; Ezekwe et al., 2013). There has been no previous research reported on the relationship between the plant and its anthophilous insects. This study was carried out to assess the effects of foraging behavior of flowering insect on pollination and yields of waterleaf. The information gained on the study could enable farmer's especially small scale farming household to develop management plans that could increase the overall quality and quantity of waterleaf yields in order to provide them a complete source of income.

\section{Materials and Methods}

Study site, experimental plot and biological material

The experiment was carried twice, April to June 2018 and 2019 at Bafut $\left(06^{\circ} 50^{\prime} \mathrm{N}\right.$ and longitude $10^{\circ} 06^{\prime} \mathrm{E}$ and $1200 \mathrm{~m}$ above sea level), Mezam, North West Region of Cameroon (Figure 1) and covers an area of roughly 340 $\mathrm{km}^{2}$ (Anonymous, 2005). Bafut is characterized by a humid sub-Equatorial climate with a rainy season from March to November which recharges groundwater and a dry season from December to February. It has a mean annual precipitation of $2657.2 \mathrm{~mm}$, humidity of $80 \%$ and temperatures ranging from $22.3^{\circ} \mathrm{C}$ to $26.7^{\circ} \mathrm{C}$ (Etia, 1980). Soils in Bafut are conditioned chiefly by topography and climate including alluvial soils, ferruginous soils and hydromorphic soils common in swampy valleys (Gavaud and Muller, 1980). The natural vegetation of Bafut is the grassland savannah, marked by grasses mixed with deciduous shrubs and stunted trees here and there, meanwhile the swampy valleys are dominated by raffia bushes and palm trees (Letouzey, 1980). This natural vegetation is strongly modified by human activities mainly farming and demographic pressure imposed by a rapidly increasing population (Acho-Chi, 1998). The experimental plot was selected in the South of Bafut at Mambu (Figure 1) and was $10 \mathrm{~m}$ long and $10 \mathrm{~m}$ wide $\left(100 \mathrm{~m}^{2}\right)$.

The biological material was represented by all the insects naturally present in the environment of study site. The Stem of $T$. triangulare (Figure 2) were provided from an already mature waterleaf farm. The vegetation near $T$. triangulare field had various spontaneous and cultivated species.

\section{Sowing and weeding}

On May 9, 2018 and 2019, the experimental plot having been previously plowed, the transplanting of the waterleaf's stem was carried out on 8 subplots of $4 \mathrm{~m}$ in length, $2 \mathrm{~m}$ in width and $50 \mathrm{~cm}$ in height each. The stems were harvested of height 5 to $7 \mathrm{~cm}$. The distance between the subplots was $50 \mathrm{~cm}$. The planting was done in line, at the rate of four lines per subplots with a spacing of $50 \mathrm{~cm}$ between the lines and $30 \mathrm{~cm}$ on the lines. For the plants to easily grow without the majority dying, it was watered till the rain was constant and plant which did not do well were replaced. Weeding was performed manually as necessary to maintain plot weeds-free.

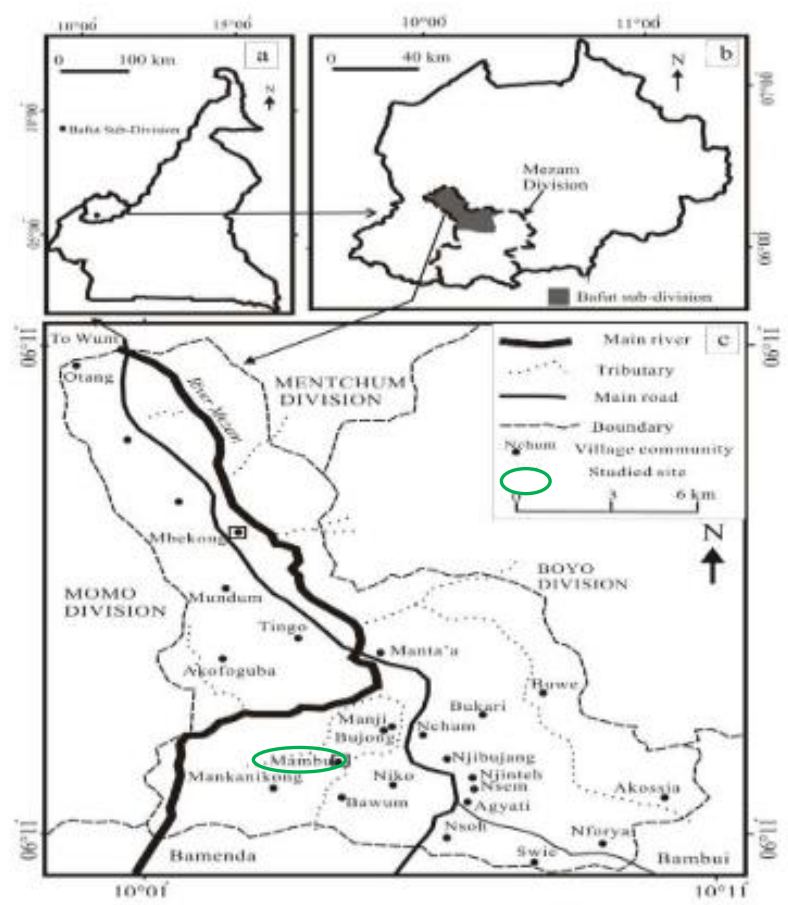

Figure 1. Study area location.

(a) Cameroon map showing position of the Bafut sub-division; (b) Map of North West Region of Cameroon locating the Bafut Sub-division; (c) Map of Bafut Sub-division (Anonymous, 2005) showing the studied site (modified by Otiobo, 2019)

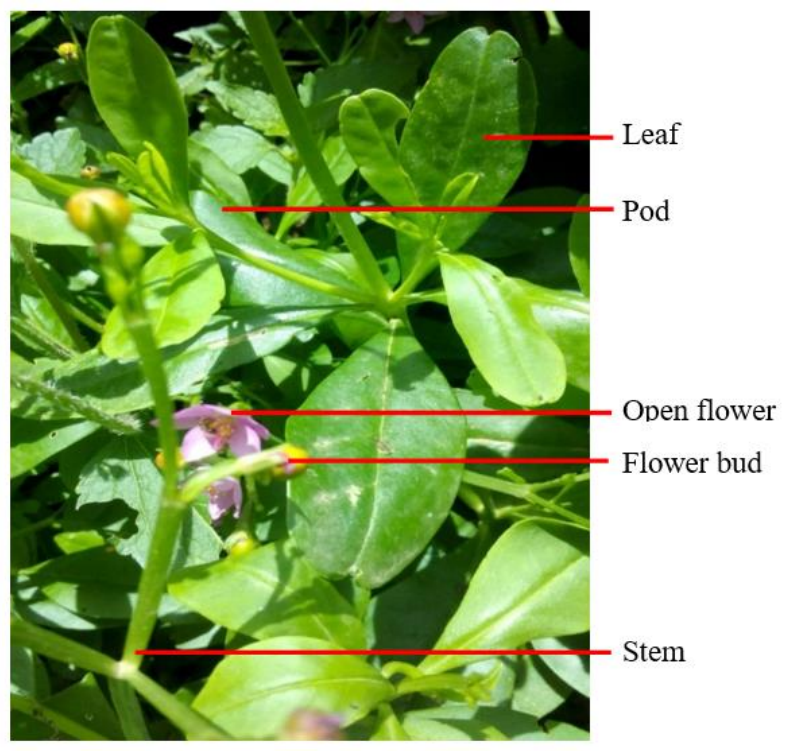

Figure 2. Talinum triangulare Plant (Otiobo, 2019)

\section{Determination of the reproduction mode of Talinum triangulare}

On $28^{\text {th }}$ May 2018, eight subplots carrying 326 plants with 3819 flowers at the bud stage were labeled. Four subplots carrying 172 plants with 2204 flowers were left un-attended (treatment 1) and four subplots carrying 154 plants with 1615 flowers were bagged to prevent visitors 
(treatment 2). On $30^{\text {th }}$ May 2019, eight subplots carrying 388 plants with 7741 flowers at the bud stage were labeled. four subplots carrying 200 plants with 4055 flowers were left un-attended (treatment 3) and foursubplots carrying 188 plants with 3686 flowers were bagged to prevent visitors (treatment 4). Twenty days after shedding of the last flower, the number of fruits was assessed in each treatment. The fruiting index $(\mathrm{Fi})$ was then calculated as described by Tchuenguem et al. (2001):

$$
\mathrm{Fi}=\mathrm{F} 1 / \mathrm{F} 2
$$

where $\mathrm{F} 2$ is the number of fruits formed and $\mathrm{F} 1$ the number of viable flowers initially set. The allogamy rate (Alr) from which derives the autogamy rate (Atr) was expressed as the difference in fruiting indexes between treatment X (unprotected flowers) and treatment Y (bagged flowers) as follows (Dermaly, 1977):

$$
\mathrm{Alr}=\left[\left(\mathrm{Fi}_{\mathrm{X}}-\mathrm{Fi}_{\mathrm{Y}}\right) / \mathrm{Fi}_{\mathrm{X}}\right] \times 100
$$

where $\mathrm{Fi}_{\mathrm{X}}$ and $\mathrm{Fi}_{\mathrm{Y}}$ are respectively the fruiting average indexes of treatments $\mathrm{X}$ and $\mathrm{Y}$.

$$
\text { Atr }=100-\text { Alr }
$$

\section{Study of the foraging activity of insects on Talinum triangulare flowers}

The methodology used was modified from that of Tchuenguem et al. (2004). The frequency of insects in the waterleaf was determined based on observations of flowers every two days, during each of the following daily time frame, from $2^{\text {th }}$ to $28^{\text {th }}$ of June 2018 and from $2^{\text {th }}$ June to $4^{\text {th }}$ July 2019: 7 - 9 am, 10 am - 12 pm, 1 - 3 pm and 4 - 6 pm. In a slow walk along all plants, the identity of all insects that visited the waterleaf was recorded. Specimens of all insect taxa were caught with an insect net and for each species, 3 to 5 insect specimens were captured. These insects were conserved in $70 \%$ ethanol for subsequent taxonomy determination except for Lepidoptera which were conserved in wrapper following Borror and White (1991) recommendations. All insects encountered on flowers were registered and the cumulated results expressed in number of visits to determine their relative frequency in the anthophilous entomofauna of waterleaf. In addition to the determination of the floral insects' frequency, direct observations of the foraging activity on flowers were made on insect pollinator fauna in the experimental field. The floral products (nectar or pollen) harvested by the insect species during each floral visit were registered based on their foraging behavior. Nectar foragers were seen extending their proboscis to the base of the corolla while pollen gatherers scratched anthers with the mandibles or the legs. During the same time that the insects encountered on flowers were registered, the types of floral products collected by those insect species were noted. In the morning of each sampling day, the number of opened flowers carried by each subplot was counted and was registered. During each daily period of observations, the temperature and relative humidity of the station were registered using a mobile thermo-hygrometer, every one hour.
Evaluation of the impact of insects on Talinum triangulare fruit yields

For each year, this evaluation was based on the impact of insect visiting flowers on pollination, the impact of pollination on fructification of waterleaf, and the comparison of fruiting rate of treatment $\mathrm{X}$ (unprotected flowers) and treatment Y (bagged flowers). At maturity, fruits grown from each treatment were harvested and were individually tagged. Comparison was done on the fruit set rate between treatments. The fruit set rate [(number of fruits formed/number of flowers formed) $\times 100$ ] was determined based on the number of flowers and the number of actual fruits formed. The percentage of the fruit set rate due to the influence of the foraging insects was calculated based on the relative difference in fruit set between bagged (treatment $2 \& 4$ ) and open-pollinated flowers (treatment 1 and 3). (Tchuenguem et al., 2004).

\section{Data analysis}

Data were analyzed using descriptive statistics, student's t-test for the comparison of means of two samples, correlation coefficient (r) for the study of the association between two variables, chi-square $\left(\chi^{2}\right)$ test for the comparison of two percentages using SPSS statistical software (version 19.0; SPSS, Inc., Chicago, Illinois, USA) and Microsoft Excel 2003.

\section{Results}

\section{Reproduction mode of Talinum triangulare}

The fruiting index of T. triangulare was $0.86,0.77,0.88$ and 0.79 , respectively for treatments $1,2,3$ and 4 . Thus, in 2018 allogamy rate was $10.60 \%$ and autogamy rate was $89.40 \%$. In 2019 , the corresponding figures were $10.74 \%$ and $89.26 \%$. For the two years combined, allogamy rate was $10.67 \%$ and autogamy rate was $89.33 \%$. It appears that T. triangulare used in our experiments has a mixed reproduction mode with the predominance of autogamy over allogamy.

\section{Diversity and abundance of flowering insects}

In total, 14 insect's species belonging to 13 Families under six Orders visiting the waterleaf plant were recorded during the two studied periods (table 1). Out of these, five species belonged to Hymenoptera $(54.34 \%)$, two to Coleoptera (27.53\%), Diptera (11.20\%;), Hemiptera $(12.38 \%)$ and Lepidoptera $(4.97 \%)$ respectively. The Orthoptera order ends with one species $(2.52 \%)$.

The hymenopterans, dipterans and lepidopterans were mostly found on the flowers. Among the hymenopteran species Camponotus flavomarginatus was the most frequent $(33.20 \%)$ insect visitor followed by ceratina $\mathrm{sp}$ (10.80\%) and Lasioglossum sp. (7.49\%), the others species (Apis mellifera and Vespa diabolica) have a percentage less than $2 \%$. The dipteran species were represented by Musca domestica (6.47\%) and Drosophila sp. (4.73\%). For lepidopterans, the two species (Acraea acerata and Papillio demodocus) were poorly represented $(<5 \%)$. Latridius sp (8.52\%) and Scirtes sp. (6.07\%) were the two species of the order Coleoptera. Hemiptera represented by Acanthicephala thomasi (4.89\%) and Lygaeus sp. (7.49\%) were mostly found sapping the plant. Order Orthoptera was poorly represented by Dissosteira Carolina species $(5.37 \%$ of the visits). 


\section{Products harvested}

On a waterleaf plant, insects collect either nectar and pollen (Apidae, Halictidae, Muscidae and Vespidae) or only nectar (Acraeidae, Drosophilidae, Formicidae, Papilionidae and Scirtidae). A part from the floral product, we have insect that suck sap from the plant (Latritidae, Lygaeidae and Coreidae). Globally, pollen and nectar collectors were numerically predominant, representing up to $76.58 \%$ of the number of visits of individuals collected on waterleaf plant.
Rhythm of visits according to the flowering stages

In general, visits were most numerous when the number of open flowers was highest (Figure 3). Furthermore, we found a positive and significant correlation between the number of open flowers and the number of insect visits in $2018\left(\mathrm{r}_{2018}=0.86[d f=26 ; \mathrm{P}<0.05]\right)$ and in $2019\left(\mathrm{r}_{2019}=\right.$ $0.89 ;[d f=32 ; \mathrm{P}<0.05])$.

Table 1. Insect species recorded on Talinum triangulare flowers in 2018 and 2019, number and percentage of visits of different insects.

\begin{tabular}{|c|c|c|c|c|c|c|c|c|}
\hline \multicolumn{3}{|c|}{ Insects } & \multicolumn{2}{|c|}{2018} & \multicolumn{2}{|c|}{2019} & \multicolumn{2}{|c|}{ Total $(2018+2019)$} \\
\hline Order & Family & Genus, species & $\mathrm{n}_{1}$ & $\mathrm{p}_{1}(\%)$ & $\mathrm{n}_{2}$ & $\mathrm{p}_{2}(\%)$ & $\mathrm{n}_{\mathrm{T}}$ & $\mathrm{p}_{\mathrm{T}}(\%)$ \\
\hline \multirow{3}{*}{ Coleoptera } & Latrididae & Latridius $\mathrm{sp}^{\alpha}$ & - & - & 108 & 16.07 & 108 & 8.52 \\
\hline & Scirtidae & Scirtes $\mathrm{sp}^{*}$ & - & - & 77 & 11.46 & 77 & 6.07 \\
\hline & Total Coleoptera & & - & - & 185 & 27.53 & 185 & 14.59 \\
\hline \multirow{3}{*}{ Diptera } & Drosophilidae & Drosophila sp.* & 33 & 5,54 & 27 & 4.02 & 60 & 4.73 \\
\hline & Muscidae & Musca domestica** & 82 & 13,76 & - & - & 82 & 6.47 \\
\hline & Total Diptera & & 115 & 19.30 & 27 & 4.02 & 142 & 11.20 \\
\hline \multirow{3}{*}{ Hemiptera } & Lygaeidae & Lygaeus $\mathrm{sp}^{\alpha}$ & - & - & 95 & 14.14 & 95 & 7.49 \\
\hline & Coreidae & Acanthicephala thomasi ${ }^{\alpha}$ & 62 & 10,40 & - & - & 62 & 4.89 \\
\hline & Total Hemiptera & & 62 & 10.40 & 95 & 14.14 & 157 & 12.38 \\
\hline \multirow{6}{*}{ Hymenoptera } & Formicidae & Camponotus flavomarginatus* & 201 & 33,72 & 220 & 32.74 & 421 & 33.20 \\
\hline & Apidae & Apis mellifera** & 11 & 1.85 & 10 & 1.49 & 21 & 1.66 \\
\hline & & ceratina $\mathrm{sp}^{* *}$ & 71 & 11.91 & 66 & 9.82 & 137 & 10.80 \\
\hline & Halictidae & Lasioglossum sp.** & 52 & 8.72 & 43 & 6.40 & 95 & 7.49 \\
\hline & Vespidae & Vespa diabolica** & 15 & 2,52 & - & - & 15 & 1.18 \\
\hline & Total Hymenopte & & 350 & 58.72 & 339 & 50.45 & 689 & 54.34 \\
\hline \multirow{3}{*}{ Lepidoptera } & Acraeidae & Acraea acerata* & 26 & 4.36 & 26 & 3.87 & 52 & 4.10 \\
\hline & Papilionidae & Papillio demodocus* & 11 & 1,85 & - & - & 11 & 0.87 \\
\hline & Total Lepidopters & & 37 & 6.21 & 26 & 3.87 & 63 & 4.97 \\
\hline \multirow{2}{*}{ Orthoptera } & Acridae & Dissosteira Carolina $^{\mu}$ & 32 & 5,37 & - & - & 32 & 2.52 \\
\hline & Total Orthoptera & & 32 & 5.37 & - & - & 32 & 2.52 \\
\hline \multirow{2}{*}{ Total } & & & & & 672 & 100 & 1268 & 100 \\
\hline & & & \multicolumn{2}{|c|}{11 species } & \multicolumn{2}{|c|}{9 species } & \multicolumn{2}{|c|}{14 species } \\
\hline
\end{tabular}

*Visitor collected nectar; ** Visitor collected nectar and pollen; $\alpha$ : Visitor sapping the plant; $\mu$ : Predator. $\mathrm{n}_{1}:$ number of visits on 2204 flowers in 14 days; $\mathrm{n}_{2}$ : number of visits on 4055 flowers in 17 days; $\mathrm{P}_{1}$ and $\mathrm{p}_{2}$ : percentages of visits; $\mathrm{p}_{1}=\left(\mathrm{n}_{1} / 596\right) \times 100 ; \mathrm{p}_{2}=\left(\mathrm{n}_{2} / 672\right) \times 100 ; \mathrm{p}_{\mathrm{T}}=\left(\mathrm{n}_{\mathrm{T}} / 1268\right) \times 100$.
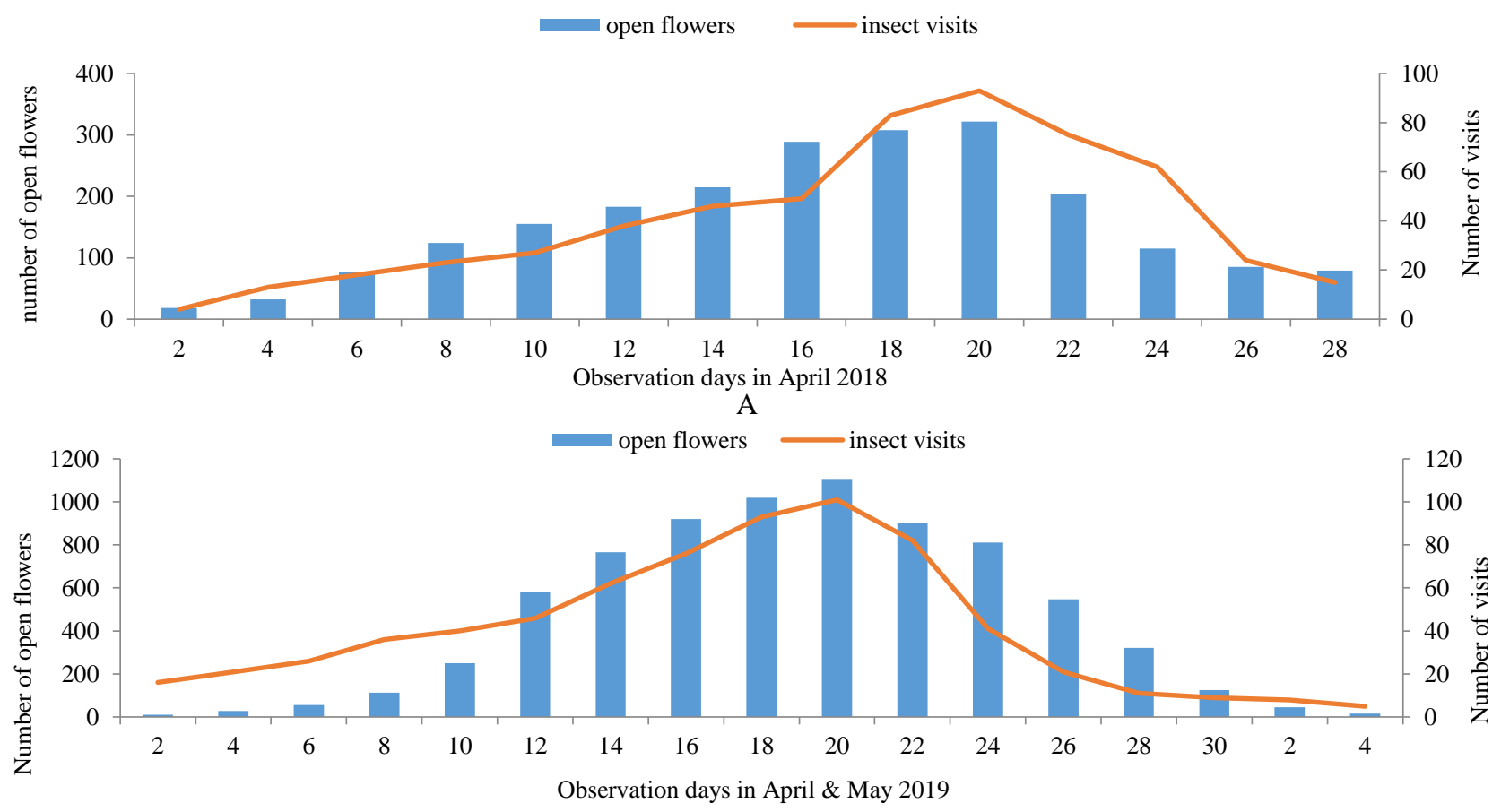

B

Figure 3. Daily variation in the number of visits of insects observed on the flowers of Talinum triangulare according to the number of blooming flowers in 2018 (A) and 2019 (B) in Bafut; Av: April, Ma : May. 
Table 2. Daily distribution of insects visits on 2204 over 14 days in 2018 and 4055 flowers over 17 days in 2019, mean temperature and mean humidity of the study site.

\begin{tabular}{cl|cccc}
\hline \multirow{2}{*}{ Year } & \multicolumn{2}{|c}{ Parameters } & \multicolumn{4}{c}{ Daily period } \\
\cline { 3 - 6 } & & $7-9 \mathrm{am}$ & $10 \mathrm{am}-12 \mathrm{pm}$ & $1-3 \mathrm{pm}$ & $4-6 \mathrm{pm}$ \\
\hline \multirow{2}{*}{2018} & Number of visits & 158 & $265^{*}$ & 137 & 36 \\
& Temperature $\left({ }^{\circ} \mathrm{C}\right)$ & 19.77 & $25.07^{*}$ & 23.47 & 20.65 \\
& Hygrometry $(\%)$ & 59.57 & $45.43^{*}$ & 42.50 & 48.07 \\
\hline \multirow{2}{*}{2019} & Number of visits & 169 & $369^{*}$ & 92 & 42 \\
& Temperature $\left({ }^{\circ} \mathrm{C}\right)$ & 19.90 & $24.57^{*}$ & 23.14 & 20.71 \\
& Hygrometry $(\%)$ & 67 & $60.53^{*}$ & 55.76 & 56.59 \\
\hline
\end{tabular}

Table 3. Fruiting rate according to the treatments of Talinum triangulare

\begin{tabular}{cc|ccc}
\hline \multirow{2}{*}{ Year } & Treatments & $\begin{array}{c}\text { Number of } \\
\text { flowers studied }\end{array}$ & $\begin{array}{c}\text { Number of } \\
\text { fruits formed }\end{array}$ & $\begin{array}{c}\text { Fructification } \\
\text { Rate }(\%)\end{array}$ \\
\hline \multirow{2}{*}{2018} & 1 (Unprotected plants) & 2204 & 1887 & 85.16 \\
& 2 (Protected plants) & 1615 & 1093 & 67.68 \\
\hline \multirow{2}{*}{2019} & 3 (Unprotected plants) & 4055 & 2733 & 67.40 \\
& 4 (Protected plants) & 3686 & 2134 & 57.89 \\
\hline \multicolumn{2}{l}{ Comparison of fruiting rates: $\chi^{2}(1 / 2)=174.97(\mathrm{df}=1, \mathrm{P}<0.005, \mathrm{VHS}) \cdot \chi_{(3 / 4)}^{2}=303.36(\mathrm{df}=1, \mathrm{P}<0.05, \mathrm{VHS})}$. \\
\hline
\end{tabular}

\section{Daily rhythm of visits}

Insect activity begins in the morning with the opening of the flowers and decreases sharply around 2 p.m. The daily period of optimal insect activity is between 10 a.m. and 12 p.m. in both 2018 and 2019 (Table 2). Climatic conditions seem to have an influence on the foraging activity of insects on waterleaf flowers. The correlation was significant between the number of insect visits and the temperature in $2018(\mathrm{r}=$ $0.68[d f=6 ; \mathrm{P}<0.05])$ and in $2019(\mathrm{r}=0.63 ;[d f=6 ; \mathrm{P}<0.05])$, then not significant between the number of insect visits and the relative humidity in $2018(\mathrm{r}=-0.06 ;[d f=6 ; \mathrm{P}>0.05])$ and in $2019(\mathrm{r}=0.39 ;[d f=6 ; \mathrm{P}>0.05])$.

Impact of insect activity on pollination and yields of Talinum triangulare

During nectar and pollen harvest from T. triangulare, foraging insects always shook flowers and are regularly made contact with the anthers and stigma, increasing the possibility of $T$. triangulare pollination. The comparison of the fruiting rate (Table 3 ) revealed that the differences observed were highly significant between treatment 1 and treatment $2\left(\chi^{2}=174.97[d f=1 ; \mathrm{P}<0.05]\right)$ and between treatment 3 and treatment $4\left(\chi^{2}=303.36[d f=1 ; \mathrm{P}<0.01]\right)$. In all the visits, Nectar and pollen collectors made contact with the anthers and stigma and carried pollen. With this pollen, they flew frequently from flower to flower of the same species. The fruit formation was higher in flowers left unprotected for unlimited visits (where high diversity of insects was observed) than in the bagged flowers. This suggests a good pollination in the crop, indicating the need for anthophilous insect's management to increase fruiting.

\section{Discussion}

In our experiments, $T$. triangulare has a mixed reproduction mode with the predominance of autogamy over allogamy. This can be explained by the fact that $T$. triangulare is a self-pollinated crop but there is the tendency of the population to be heterogenous due to their floral propensity for insect pollinations (Gill, 1988). In habitats where pollinators are available, the species is likely to show mixed mating system involving both cross- pollination as a result of floral visitors and autogamy by perianth closing (Shivanna, 2019). Such a mechanism gives the species resilience under pollinator constraint as a means of reproductive assurance (Kalisz and Vogler, 2003; Eckert et al., 2006, 2010; Shivanna, 2014, 2015)

Flowers of $T$. triangulare are actinomorphic and of open type; any floral visitor is able to harvest the reward (Pellmyr, 2002). On a T. triangulare flowers, insects harvested nectar (Scirtidae, Drosophilidae, Formicidae, Acraeidae, Papilionidae, Muscidae, Apidae, Halictidae) this results is in accordance with some authors results whom found that Pollinators like bees, ants, grasshopper and flies visit waterleaf flowers due to the rich nectar they have (Stevels, 1990). In addition to the nectar, some insects also collected pollen (Muscidae, Apidae, Halictidae) while others sucks the sap (Latrididae, Lygaeidae, Coreidae) and one group is predator (Acridae). These insects' predators' help to control the populations of other insect's species in the farm (Ewusie and Quaye, 1977). These different diets are based on their feeding strategies. This diversity of insect herbivores reflects diversity in diet and feeding behavior (Bernays, 1998). Our studies revealed that waterleaf plant attracted broad range of insects. Among those insect species, Camponotus flavomarginatus (ant) was the most frequent insect on the T. triangulare plants where they moved up and down linearly on the different parts of the plant, this was due to the fact that they are extremely abundant in most ecosystems. Several authors have acknowledged the fact that ants could aid in pollination in different ways (Oliveira et al., 1999; Gomez, 2000; Ghazoul, 2001; Philpott et al., 2006).

the presence of insects on the experimental plot were high in the morning from $10 \mathrm{am}$ to $12 \mathrm{pm}$ and is correlated with the availability of nectar and/or pollen in $T$. triangulare flowers; similarly, this is the period during which the stigma of waterleaf flowers has optimal receptivity for pollen or the weather conditions. In fact, Bramel et al. (2004) reported that the weather during bloom affects abundance and foraging of insect pollinators. Insects as poikilothermic animals change their activity visibly depending on the temperature of the surrounding environment (Bale et al., 2002; Menéndez et al., 2007). 
The positive and significant correlation between the number of open waterleaf flowers and the number of insect visits highlights the high attractiveness of the nectar and / or pollen of this Portulacaceae to insects. Insects carry pollen from flower to flower and can thus play a positive role in geitonogamy (Rosa et al., 2011), by placing the pollen of one flower on the stigma of another flower of the same plant. Insects that pass from flower to flower on different plants carry pollen from one plant to another. They can thus promote xenogamy (Rosa et al., 2011), by putting the pollen of one plant on the stigma of a flower of another plant. The latter form of pollination is all the more likely as allogamy exists in $T$. triangulare as also reported by Rachman (2008). The insects shake the flowers during their visits. These movements would facilitate the optimal release of pollen for the occupation of the stigma. The optimal pollen load on the stigma would be favorable for the formation of fruits and seeds

The positive and significant contribution of insects in the fruit yields of waterleaf is justified by their actions on pollination. The fruit yields recorded in all the treatment can be attributed to the predominance of autogamy of this specie and the important role of the pollinating insects. The flowers that were exposed to pollinators provided more fruits than protected plants; this result is in agreement to previous results reported on $T$. triangulare crop in Indonesia (Rachman, 2002). According to McGregor (1976), Fruiting is mainly dependent on the intensity of pollination.

\section{Conclusion}

Talinum triangulare is a plant species that benefits from the foraging activity of a broad range of insects species. 14 species of insects distributed into six Orders visited the flowers of $T$. triangulare to harvest nectar and/or pollen. These insects foraged the flowers of this plant species from 7 am to $6 \mathrm{pm}$, with a peak activity located between $10 \mathrm{am}$ and $12 \mathrm{pm}$. T. triangulare is plant that benefits from pollination by insects despite is capacity of self-pollination. The significant increase in yields of $T$. triangulare in the presence of anthophilous insects is the consequence of the foraging activity of these insect species on the pollination of the flowers of the plant studied. Installation and preservation of insect nests near the population of $T$. triangulare should be recommended in order to benefit from the ecosystem service of pollinating insects thus increasing in fruit yield of Waterleaf

\section{Acknowledgements}

The authors thank all those who facilitated this work, especially Youmbi Chirelle Audrey and Shu Constance Bi for their help in data collection.

\section{References}

Acho-Chi. 1998. Human interference and environmental instability: Addressing the environmental consequences of rapid urban growth in Bamenda, Cameroon. Environment and Urbanization, 10(2), 161-174. Doi: https://doi.org/10.1177/ 095624789801000206.

Aduku AO, Olukosi JO. 1990. Rabbit management in the tropics: Production, Processing, Utilization, Marketing, Economics, Practical Training, Research and Future Prospects. Living book Series, GU Publication FCT, Abuja, 24, 1-105.
Aja PM, Okaka ANC, Onu PN, Ibiam U, Urako AJ. 2010. Phytochemical composition of Talinum triangulare (water leaf) leaves. Pakistan Journal of Nutrition, 9(6), 527-530. Doi: 10.3923/pjn.2010.527.530.

Anonymous 2005. Presentation of the Bafut Village Community Project. VCP: Bafut, Cameroon

Bale JS, Masters GJ, Hodkinson ID, Awmack CS, Bezemer TM, Brown VK, Butterfield J, Buse A, Coulson JC, Farrar J, Good JEG, Harrington R, Hartley S, Jones TH, Lindroth RL, Press MC, Smyrnioudis I, Watt AT, Whittaker JB. 2002. Herbivory in global climate change research: direct effects of rising temperature on insect herbivores. Global change Biology, 8(1), 1-16. Doi: https://doi.org/10.1046/j.1365-2486.2002.00451.x.

Bernays EA. 1998. Evolution of feeding behavior in insect herbivores. Bioscience, 48(1), 35-44. Doi: https://doi.org/ 10.2307/1313226.

Borror DJ, White RE. 1991. North America insects (North of Mexico). Broquet (Eds) (pp. 408): The Prairie-Quebec, ISBN 10: 2890002446, ISBN 13: 9782890002449.

Bramel J, Kiran S, Reddy J, Ford-Lloyd B, Chandra S. 2004. Degree and distribution of Pigeon pea landrace morphological diversity in traditional cropping systems in Andhra Pradesh. Assessing the risk of losses of biodiversity in traditional cropping systems: A case study of Pigeon pea in Andhra Pradesh. International Crops Research Institute for the SemiArid Tropics, Pantacheru, Andhra Pradesh, Indian, 1-45.

Dremaly Y. 1977. Génétique et amelioration des plantes. Masson, Paris, ISBN : 2225457603, 9782225457609.

Eckert CG, Kalisz S, Geber MA, Sargent R, Elle E, Cheptou PO, Goodwillie C, Johnston MO, Kelly JK, Moeller DA, Porcher E, Ree RH, Vallejo-Marín M, Winn AA. 2010. Plant mating systems in a changing world. Trends in Ecology \& Evolution, 25(1), 35-43. doi: 10.1016/j.tree.2009.06.013.

Eckert CG, Samis KE, Dart S. 2006. Reproductive assurance and the evolution of uniparental reproduction in flowering plants. Ecology and evolution of flowers, 183, 203.

Enete AA, Okon UE. 2010. Economics of Waterleaf (Talinum triangulare) Production in Akwa Ibom State, Nigeria. Field Actions Science Reports. The journal of field actions, 4. URL: http://journals.openedition.org/factsreports/438.

Etia PM. 1980. Climate and climatic zones of Cameroon. In: JA, editor. Les Atlas Jeune Afrique: Paris, France.

Ewusie JY, Quaye EC. 1977. Diurnal periodicity in some common flowers. The New Phytologist, 78(2), 479-485. Retrieved February 11, 2021, from http://www.jstor.org/ stable/2433375.

Ezekwe CI, Uzomba CR, Ugwu OPC. 2013. The effect of methanol extract of Talinum triangulare (water leaf) on the hematology and some liver parameters of experimental rats. Global Journal of Biotechnology and Biochemistry, 8(2), 5160. Doi: 10.5829/idosi.wasj.2013.25.07.7629.

Fontem DA, Schippers RR. 2004. Talinum triangulare (Jacq.) Willd [Internet] record from protabase. Plant resources of tropical Africa. Wageningen, the Netherlands. <http://www. prota4u.org/search.asp>.

Gavaud M, Muller JP. 1980. Soil map of Cameroon. In: JA, editor. Les Atlas Jeune Afrique: Paris, France.

Ghazoul J. 2001. Can floral repellents pre-empt potential antplant conflicts?. Ecology Letters, 4(4), 295-299. Doi: https://doi.org/10.1046/j.1461-0248.2001.00229.x.

Gill LS. 1988. Taxonomy of flowering plants. Africana-Fep Publishers Limited, 1067

Gómez JM. 2000. Effectiveness of ants as pollinators of Lobularia maritima: effects on main sequential fitness components of the host plant. Oecologia, 122(1), 90-97. Doi : https://doi.org/10.1007/PL00008840.

Herrera A. 1999. Effects of photoperiod and drought on the induction of crassulacean acid metabolism and the reproduction of plants of Talinum triangulare. Canadian Journal of Botany, 77(3), 404-409. Doi: https://doi.org/ 10.1139/b99-036. 
Kalisz S, Vogler DW. 2003. Benefits of autonomous selfing under unpredictable pollinator environments. Ecology, 84(11), 2928-2942. Doi: https://doi.org/10.1890/02-0519

Letouzey R. 1980. Phytogeographic map of Cameron. In: JA, editor. Les Atlas Jeune Afrique: Paris, France.

Liang D, Zhou Q, Gong W, Wang Y, Nie Z, He H, Li J, Wu J, Wu C, Zhang J. 2011. Studies on the antioxidant and hepatoprotective activities of polysaccharides from Talinum triangulare. Journal of ethnopharmacology, 136(2), 316-321. Doi: 10.1016/j.jep.2011.04.047.

McGregor SE. 1976. Insect pollination of cultivated crop plants (Agriculture handbook No. 496). Agricultural Research Service, US Department of Agriculture.

Menéndez R, González-Megías A, Collingham Y, Fox R, Roy DB, Ohlemüller R. Thomas C. D. (2007). Direct and indirect effects of climate and habitat factors on butterfly diversity. Ecology, 88(3), 605-611. Doi: 10.1890/06-0539.

Mensah JK, Okoli RI, Ohaju-Obodo JO, Eifediyi K. 2008. Phytochemical, nutritional and medical properties of some leafy vegetables consumed by Edo people of Nigeria. African journal of Biotechnology, 7(14), 2304-2309.Available online at http://www.academicjournals.org/AJB ISSN 1684-5315

Ndaeyo NU, Ikeh AO, Nkeme KK, Akpan EA, Udoh EI. 2013. Growth and foliar yield responses of waterleaf (Talinum triangulare Jacq) to complementary application of organic and inorganic fertilizers in a ultisol. American Journal of experimental Agriculture, 3(2), 324-335. Doi : http://doi.org/ 10.5281/zenodo.8228.

Nworgu FC, Alikwe PC, Egbunike GN. Ohimain EI. 2015. Economic Importance and Growth Rate of Broiler Chickens Fed with Water Leaf (Talinum triangulare) Meal Supplements. Asian Journal of Agricultural Extension, Economics \& Sociology, 49-57. Doi: https://doi.org/ 10.9734/AJAEES/2015/12542

Okpala B. 2016. Worthy benefits of water Leaf: Published on July 5, 2016 in Global Food Book Recipes for Life

Oliveira PS, Rico-Gray V, Castillo-Guevara CDCAC. 1999. Interaction between ants, extrafloral nectaries and insect herbivores in Neotropical coastal sand dunes: herbivore deterrence by visiting ants increases fruit set in Opuntia stricta (Cactaceae). Functional ecology, 13(5), 623-631. Doi: https://doi.org/10.1046/j.1365-2435.1999.00360.x

Opabode JT, Adebooye OC. 2005. Application of biotechnology for the improvement of Nigerian indigenous leaf vegetables. African Journal of Biotechnology, 4(3), 138-142.

Pellmyr O. 2002. Pollination by animals. Plant-animal interactions, an evolutionary approach, 157-184.
Philpott SM, Uno S, Maldonado J. 2006. The importance of ants and high-shade management to coffee pollination and fruit weight in Chiapas, Mexico. In Arthropod Diversity and Conservation (pp. 473-487). Springer, Dordrecht. Doi: https://doi.org/10.1007/s10531-005-0602-1

Rachman E. 2002. Pollination systems and seed production relation and autonomous pollination capacity of Javanese ginseng, Talinum triangulare Wild. Ilmu dan Budaya (Indonesia). Indonesian Center for Agricultural Library and Technology Dissemination, AGRIS, 22, 50-55.

Rachman E. 2008. Sistem Penyerbukan Alternatif Talinum Triangulare Willd.: Efek Perlakuan Penyerbukan Pad A Aktifitas Bunga Dan Pembentukan Bui. Berita Biologi, 9(2), 133-138. Doi: 10.14203/beritabiologi.v9i2.2021.

Rosa ADS, Blochtein B, Lima DK. 2011. Honey bee contribution to canola pollination in Southern Brazil. Scientia Agricola, 68(2), 255-259. Doi: http://dx.doi.org/10.1590/S010390162011000200018.

Schippers RR. 2000. African indigenous vegetables. An overview of the cultivated species. Natural Resources Institute/ACPEU Technical Centre for Agricultural and Rural Cooperation, Chatham, United Kingdom. 214 pp. URL: http://r4d.dfid.gov.uk/Output/179575/

Shivanna K. 2014. Reproductive assurance through autogamy in some annual weed species. Proceedings of the National Academy of Sciences, India Section B: Biological Sciences, 84(3), 681-687. Doi: https://doi.org/10.1007/s40011-0140307-x

Shivanna KR. 2015. Reproductive assurance through autogamous self-pollination across diverse sexual and breeding systems. $\begin{array}{llll}\text { Current } & \text { Science 109, 1255-1263. Doi: }\end{array}$ 10.18520/v109/i7/1255-1263.

Shivanna KR. 2019. A Novel Autogamous Self-Pollination Strategy Involving Closing of Perianth Lobes in Talinum fruticosum (L.) Juss. Proceedings of the National Academy of Sciences, India Section B: Biological Sciences, 89(4), 1407-1411. Doi: 10.1007/s40011-018-01066-6

Siemonsma JS, Piluek K. 1993. Plant resources of South-East Asia no. 8: vegetables (No. BOOK). Pudoc Scientific Publishers. ISBN 90-220-1058-9

Stevels JMC. 1990. Légumes traditionnels du Cameroun, une étude agro-botanique. Agricultural University. ISBN $9789067541510-262$

Tchuenguem FF-N, Messi J, Brüchner D, Bouba B, Mbofung G. Hemo JH. 2004. Foraging and pollination behavior of the African Honey bee (Apis mellifera adansonii) on Callistemon rigidus flowers in Ngaoundere (Cameroon). Journal of the Cameroon Academy of Sciences, 4(2), 133-140.

Tchuenguem FFN, Messi J, Pauly A. 2001. Activité de Meliponula erythra sur les fleurs de Dacryodes edulis et son impact sur la fructification. Fruits 56(3), 179-188. Doi:10.1051/fruits:2001121. 